\title{
Pinealectomy delays puberty in ewe lambs
}

\author{
D. J. Kennaway, T. A. Gilmore and E. A. Dunstan* \\ Department of Obstetrics and Gynaecology, University of Adelaide, Queen Elizabeth Hospital, \\ Woodville Road, Woodville, South Australia 5011 and *Department of Agriculture, Kybybolite \\ Research Centre, Kybybolite, South Australia 5262, Australia
}

\begin{abstract}
Summary. Fifteen pinealectomized and 15 unoperated ewes were exposed to constant light for 3 weeks before and 10 weeks after lambing. Fourteen pinealectomized and 15 unoperated ewes were allowed to lamb outdoors. Five ewe lambs born in constant light to the 2 groups of dams were pinealectomized at 10 weeks of age. Ewes and lambs were then returned to the field. Puberty (determined by weekly progesterone analysis) was significantly delayed $(P<0.05)$ in the pinealectomized ewe lambs. Median pubertal age in pineal-intact ewe lambs was 37 weeks compared to 49 weeks in pinealectomized lambs. Constant light during the first 10 weeks of life had no effect upon puberty onset nor did the pineal status of the dam. Control lambs entered seasonal anoestrus at the time pinealectomized ewe lambs were entering puberty. Pinealectomized lambs entered anoestrus at the same time as control lambs were beginning their second breeding season. These results confirm a key role of pineal-mediated hormonal signals in the control of puberty in the sheep.
\end{abstract}

\section{Introduction}

The timing of puberty in ewe lambs is a result of an interaction between physical maturity and the prevailing photoperiod (Foster \& Ryan, 1981). Once lambs have reached an optimal body weight and daylength is decreasing, the various endocrine events leading to oestrus, ovulation and subsequent pregnancy are facilitated. While there is no question that young lambs can be stimulated artificially to produce an LH surge and to ovulate (Quirke, 1981), it is apparent that there are inhibitory factors preventing these events from occurring prematurely. Ewe lambs do have regular, low-frequency, high-amplitude LH secretory episodes from a very early age (Foster, Lemons, Jaffe \& Niswender, 1975). Lambs also exhibit a photoperiod-controlled hypersensitivity to the negative feedback actions of oestradiol similar to that reported for adult ewes (Legan \& Karsch, 1977; Foster, 1981a). It was suggested that this phenomenon was a contributing factor to the delayed puberty seen in autumn-born lambs and Foster (1981b) and Yellon \& Foster (1982a, b) have substantiated the profound effects of daylength pattern upon puberty onset : at least 5 weeks of long daylength are required between 10 and 20 weeks of age followed by short daylength for puberty to occur at the normal time.

There is now considerable evidence that photoperiodic cues are of critical importance in determining the seasonal onset of reproductive competence in female sheep (Hafez, 1952; Ducker, Thwaites \& Bowman, 1970; Legan \& Karsch, 1977; Kennaway, Sanford, Godfrey \& Friesen, 1983). The pineal gland, through its hormone melatonin, is one of the key endocrine organs mediating photoperiodic effects on the hypothalamo/pituitary axis (Bittman, Dempsey \& Karsch, 1983). Since photoperiod is involved in the timing of the breeding season in adult ewes and the onset of puberty in ewe lambs, we have suggested that the pineal gland may be involved in both situations (Kennaway \& Gilmore, 1984). We have previously reported that constant administration of melatonin from 3 weeks of age inhibits puberty in ewe lambs (Kennaway \& Gilmore, 1984) while not profoundly altering hormonal profiles in rams (Kennaway \& Gilmore, 1985). Removal of the 
pineal gland early in development might be expected to advance the time of puberty if the pineal was simply exerting a 'tonic' inhibitory action or it might delay puberty if the animal requires more specific information about daylength. This paper reports the effects of pinealectomy at 10 weeks of age on the onset of oestrous activity and plasma progesterone levels in ewe lambs. The lambs were born to dams which themselves had previously been sham-operated or pinealectomized as in the previous study (Kennaway \& Gilmore, 1984) to determine whether there was any intrauterine programming of puberty by maternal pineal influences.

\section{Materials and Methods}

The experiment was conducted at the Mortlock Experiment Station, Mintaro, South Australia, between February 1982 and November 1983. Fifty-nine Saxon Merino $\times$ Border Leicester ewes (6.5 years of age) were used to provide the lambs for this study: 29 ewes had been pinealectomized 6 years previously by the method of Kennaway, Obst, Dunstan \& Friesen (1981a). In February 1982 all cyclic ewes $(\mathrm{N}=45)$ were injected with $125 \mu \mathrm{g}$ cloprostenol (Estrumate: ICI Ltd, Sydney, NSW) on two occasions, 14 days apart. The remaining 14 non-cyclic ewes were treated over the same period with intravaginal sponges containing $60 \mathrm{mg}$ medroxyprogesterone acetate (Repromap: UpJohn Pty Ltd, Rydalmere, NSW). On the 3rd day after the second cloprostenol injection or 3 days after sponge removal the ewes were injected with 400 i.u. PMSG (Folligon: Intervet (Aust) Pty Ltd, Artarmon, NSW). These treatments were applied to synchronize the mating of the ewes and to increase the twinning rate a little in this low fecundity breed. Fertile, harnessed Dorset rams were then run with the flock and mating dates recorded. At 3 weeks before the expected time of lambing 30 ewes thought to be bearing twins (based on progesterone concentrations at Day 100 of pregnancy) were moved into a light-proof shed where rows of fluorescent lights were on continuously to suppress endogenous melatonin secretion (Rollag \& Niswender, 1976) in lambs during the subsequent 13 weeks. Fifteen ewe lambs ( 3 sets of twin ewes) were born to unoperated (Group C) ewes in constant light and 5 ewe lambs ( 1 set of twin ewes) to ewes maintained in the field. Nine ewe lambs ( 1 set of twin ewes) were born to pinealectomized dams in constant light and 6 to pinealectomized ewes in the field (Group P). Ram lambs produced in this experiment were castrated after birth and run as a separate flock after weaning at 14 weeks.

When the ewe lambs were 8-12 weeks of age, lambs born in constant light to Group C dams and 5 lambs born in constant light to Group P dams were pinealectomized by the method of Kennaway et al. (1981a) to provide Groups $\mathrm{Cp}$ and $\mathrm{Pp}$. When isosexual twins were available, one twin was pinealectomized and the other left intact. Completeness of the pinealectomy was determined at the time of the operation by macroscopic inspection of the pineal gland. Four ewe lambs born to Group $\mathrm{C}$ dams in constant light were not used in this experiment. Ewe lambs born to ewes in Groups $\mathrm{C}$ and $\mathrm{P}$ in constant light and outdoors were designated Groups $\mathrm{Cu}$ and $\mathrm{Pu}$ and $\mathrm{Co}$ and Po respectively. Table 1 summarizes the treatments. The pinealectomized ewe lambs showed excellent recovery and were returned to the field with other ewes and lambs 3 days after surgery. One animal in Group $\mathrm{Cp}$ died 8 weeks after pinealectomy (cause of death was not determined).

Table 1. Treatments applied to the groups of ewe lambs

\begin{tabular}{lccccc}
\hline & $\begin{array}{c}\text { No. of } \\
\text { lambs }\end{array}$ & $\begin{array}{c}\text { Maternal pineal } \\
\text { status }\end{array}$ & $\begin{array}{c}\text { Constant light } \\
\text { for first 10 } \\
\text { weeks of life }\end{array}$ & $\begin{array}{c}\text { Lamb pineal } \\
\text { status }\end{array}$ & $\begin{array}{c}\text { Day of the } \\
\text { year born* }\end{array}$ \\
\hline Group Cu & 5 & Intact & Yes & Intact & $221 \pm 12$ \\
Group Cp & 5 & Intact & Yes & Pinealectomized & $222 \pm 10$ \\
Group Co & 5 & Intact & No & Intact & $220 \pm 4$ \\
Group Pu & 4 & Pinealectomized & Yes & Intact & $220 \pm 1$ \\
Group Pp & 5 & Pinealectomized & Yes & Pinealectomized & $224 \pm 8$ \\
Group Po & 5 & Pinealectomized & No & Intact & $222 \pm 11$ \\
\hline
\end{tabular}

*Day $1=1$ January. Values are mean \pm s.d. 
Blood samples were obtained weekly for 72 weeks by jugular venepuncture. Animals were weighed every 2 nd week and were weaned at 14 weeks of age. At weaning a ram fitted with a marking harness was run with the flock to detect oestrus. Plasma progesterone was assayed using the RIA described by (Janson, Amato, Weiss, Ralph \& Seamark, 1978). Sensitivity was $<0.5$ $\mathrm{nmol} / \mathrm{l}$ and intra- and inter-assay coefficients of variation at $7 \mathrm{nmol} / 1$ were $<12 \%$. Statistical differences between groups were determined by the Mann-Whitney U-test or Student's $t$ test.

\section{Results}

Ewe lambs born in constant light were $0.3-0.6 \mathrm{~kg}$ lighter than ewe lambs born in the field. This differential was maintained at 10 weeks of age with lambs born outside being 3-5 kg heavier. At 37 weeks of age lambs in Groups Co and Po were significantly heavier $(P<0.05)$ than those in Groups $\mathrm{Cu}$ and $\mathrm{Pu}$ (Table 2). There was no significant weight difference between the unoperated and pinealectomized ewes born indoors (Groups $\mathrm{Cu}$ and $\mathrm{Cp}$ ). A contributing factor to the weight difference between the lambs raised indoors and those raised outdoors was the higher incidence of twins in the groups born indoors (10 sets of male-female and female-female twins vs 1 set of female-female twins). Text-figure 1 shows the plasma progesterone concentrations and occurrence of oestrus of all the ewe lambs in this study. The time of onset of puberty was defined as the first occasion progesterone levels exceeded $1.5 \mathrm{nmol} / 1$. In our experience with mature ewes, this level of progesterone is indicative of normal luteal function, but the use of weekly blood sampling cannot be reliably used on its own to distinguish normal luteal cycles from short cycles. At various times during the first breeding season some lambs were not marked by rams despite apparently normal luteal function. Similarly some ewes were marked when there was no subsequent luteal activity. In our experience the detection of oestrus with raddled rams in young sheep is often unreliable. After 1 November 1983 only the records of oestrus were used because in their second season ewes show regular mating patterns. Puberty occurred between 32 and 39 weeks of age (22 March-26 April 1983) in 18 of the 20 ewe lambs in Groups $\mathrm{Cu}, \mathrm{Co}, \mathrm{Pu}$ and Po. The remaining 2 animals failed to exhibit cyclic progesterone concentrations during the study. In contrast, puberty in the pinealectomized ewe lambs in Groups $\mathrm{Cp}$ and $\mathrm{Pp}$ was significantly delayed $(P<0.05)$, occurring between 40 and 55 weeks of age in 8 out of 10 animals with 2 lambs again failing to show cyclic progesterone levels. Anoestrus was defined as the first week in which progesterone was undetectable for at least 3 weeks. The unoperated ewe lambs ceased cyclic activity at 39-60 weeks of age (15 animals; 31 May-4 October 1983) while 3 ewe lambs cycled continuously. The onset of anoestrus in the pinealectomized animals occurred in 8 of the remaining animals on 23 February 1984 (median, 95\% confidence interval (CI) 29 January-27 February 1983). One animal died after its first oestrus and ovulation and one ewe has continued to show regular oestrous behaviour since 2 May 1983. The median time of onset of the second breeding season in the control groups was 12 March 1984 (CI; 10 January-2 April 1984). Two animals have cycled continuously from 21 June

Table 2. The birthweight, weight at time of pinealectomy, age at puberty, weight at puberty and age at anoestrus of ewe lambs

\begin{tabular}{|c|c|c|c|c|c|c|}
\hline & Group $\mathrm{Cu}$ & Group Co & Group Cp & Group $\mathrm{Pu}$ & Group Po & Group Pp \\
\hline No. of lambs & 5 & 5 & 5 & 4 & 5 & 5 \\
\hline Birth weight $(\mathrm{kg})$ & $3.8 \pm 0.5$ & $4 \cdot 5 \pm 0 \cdot 3$ & $3.8 \pm 0.6$ & $4.6 \pm 0.7$ & $5 \cdot 0 \pm 0 \cdot 4$ & $4.5 \pm 1.0$ \\
\hline $\begin{array}{l}\text { Weight at } 10 \text { weeks }(\mathrm{kg}) \\
\text { Median age at puberty (weeks) }\end{array}$ & $19 \cdot 3 \pm \frac{ \pm}{38} 2 \cdot 3$ & $23 \cdot 8 \underset{36}{ \pm} 3 \cdot 3$ & $18 \cdot 3 \pm \frac{ \pm}{49} 4 \cdot 3$ & $22 \cdot 7 \frac{ \pm}{36}^{3 \cdot 1}$ & $25 \cdot 4 \underset{36}{ \pm} 3 \cdot 3$ & $20 \cdot 7 \underset{49}{ \pm} 2 \cdot 6$ \\
\hline Weight at 37 weeks $(\mathrm{kg})$ & $35 \cdot 6 \pm 3 \cdot 5$ & $43.9 \pm 4 \cdot 4$ & $33 \cdot 3 \pm 3.0$ & $41 \cdot 1 \pm 4 \cdot 2$ & $44 \cdot 7 \pm 4 \cdot 3$ & $37 \cdot 3 \pm 3 \cdot 1$ \\
\hline $\begin{array}{l}\text { Median age at first anoestrus } \\
\text { (weeks) }\end{array}$ & $5 \overline{3}$ & $4 \overline{8}$ & 二 & $4 \overline{8}$ & $4 \overline{5}$ & 二 \\
\hline
\end{tabular}



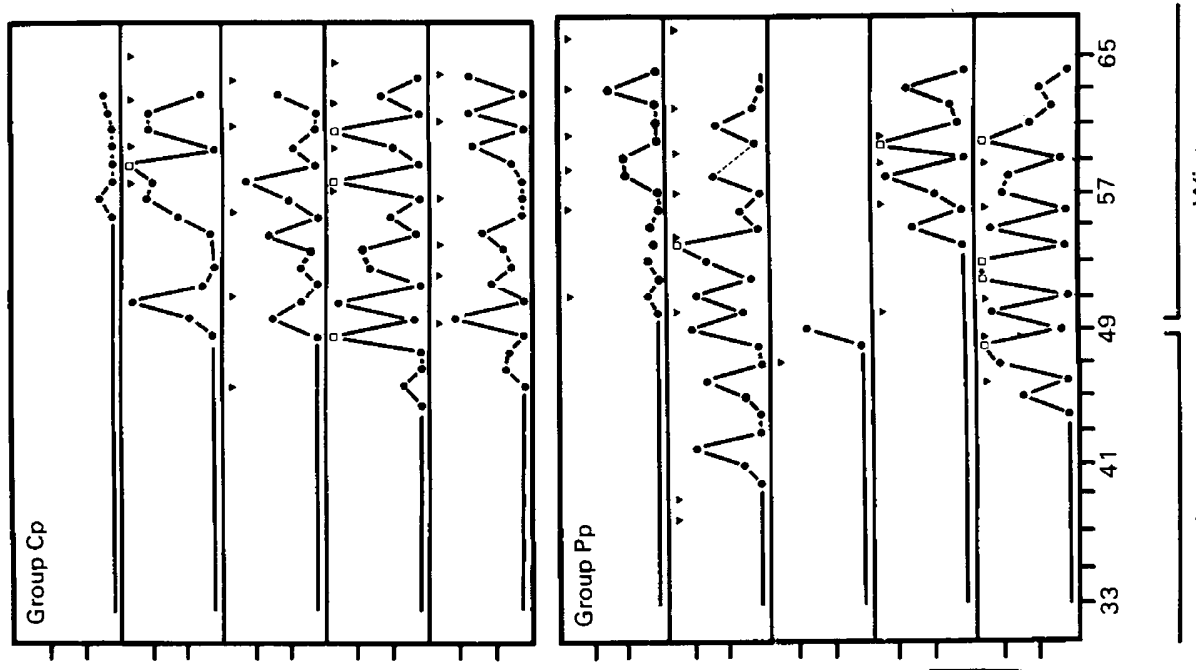

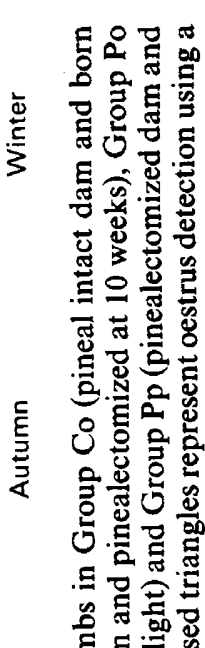
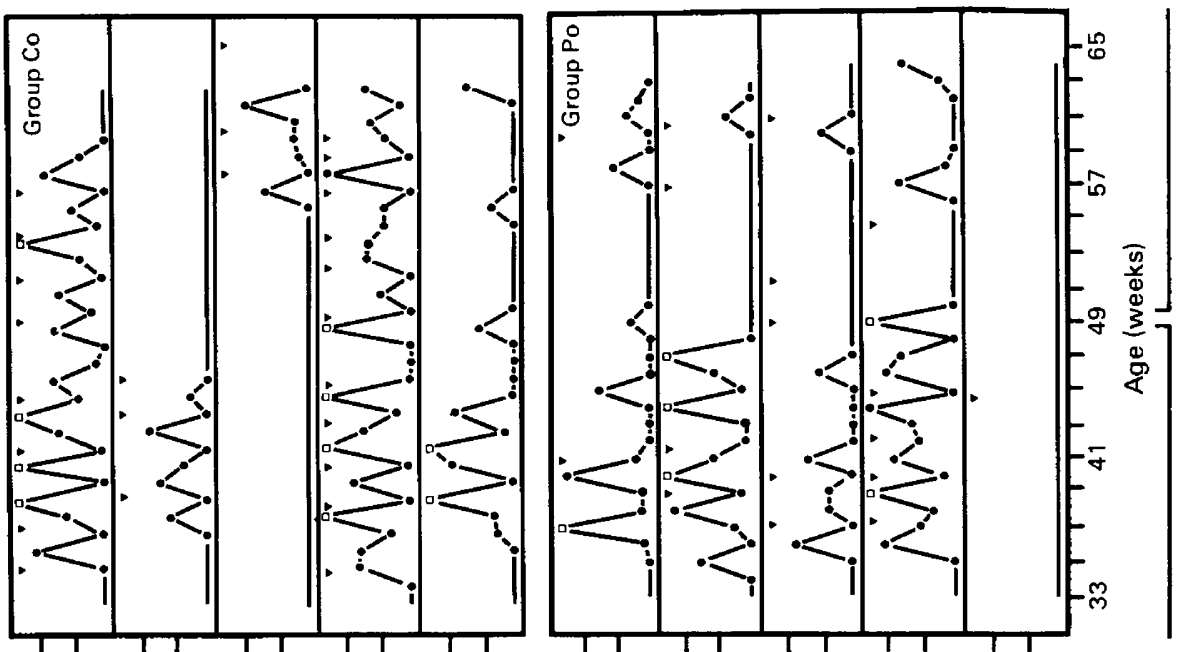

토 홍

卷芯

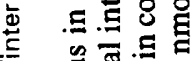

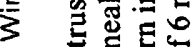

氥 눙

论氞过

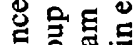

휸현.

500

ᄃ

을

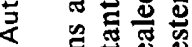

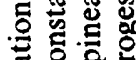

준 0 응

들

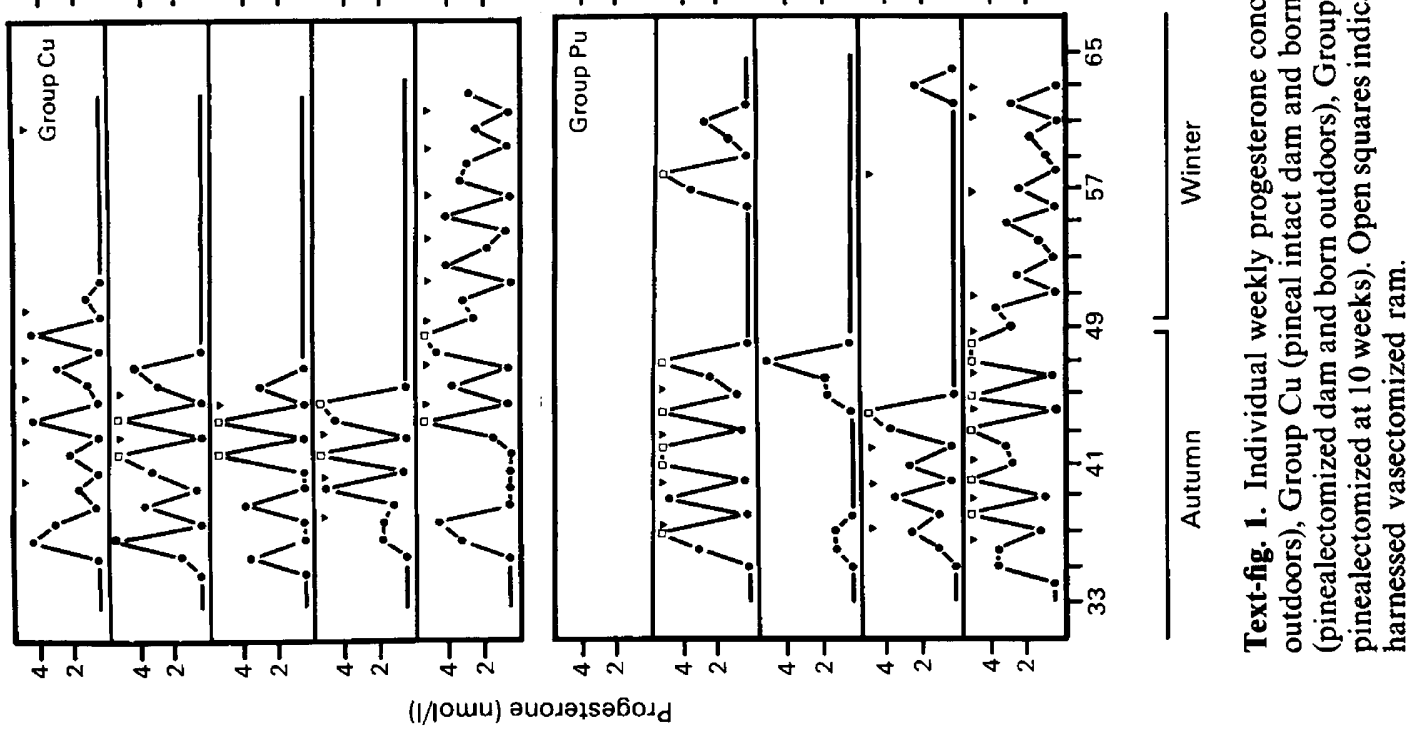


1983 and 20 September 1983. Some control animals had sporadic ovulatory cycles in late winter and early spring. The presence or absence of a maternal pineal gland had no effect upon puberty onset in this experiment.

\section{Discussion}

Pinealectomy at 10 weeks of age delayed puberty onset by approximately 13 weeks. Pinealectomized lambs were in fact having their first ovulatory cycles when the control lambs were entering anoestrus. As in our previous work (Kennaway \& Gilmore, 1984) lambs were reared in constant light before pinealectomy to suppress melatonin secretion (Rollag \& Niswender, 1977) in case pineal melatonin secretion in the first 10 weeks of life was the cue for the time of puberty. If this was the case, pinealectomy may not have had an effect. However, 10 weeks of constant light had no influence upon puberty onset since lambs reared in the field began cycles at the same age. Therefore, the delay in puberty noted in this study is directly attributable to the absence of the pineal gland. The absence of a pineal gland in the dam had no effect upon the onset of puberty of the ewe lamb. While this was considered a remote possibility, melatonin from the ewe can cross the placenta to the fetus and may be a means of entraining the offspring to the prevailing photoperiod (Kennaway, Matthews \& Seamark, 1981b).

Anoestrus in the pinealectomized ewe lambs occurred at about the time the control animals were entering their second breeding season (autumn 1984). This indicates that neonatal pinealectomy had profound long-term consequences, with the result that breeding activity was no longer entrained to the prevailing environmental conditions. The fact that pinealectomized animals did reach full sexual maturity is evidence of an innate drive within the reproductive axis, ensuring that even under extreme environmental conditions some animals will still breed. The occurrence of an anoestrous interval in these animals provides evidence that sheep cannot normally sustain ovulatory cycles indefinitely.

The present study of neonatal pinealectomy can be compared with our previous study in which ewe lambs born to the same dams were treated with melatonin implants (Kennaway \& Gilmore, 1984). Pinealectomy might have been expected to advance puberty since any photoperiodic cues normally transmitted through the pineal to inhibit puberty would have been absent. The delayed puberty after pinealectomy appears contradictory to the results obtained with constant administration of the pineal hormone, melatonin, since that treatment also considerably delayed puberty onset (Kennaway \& Gilmore, 1984).

Yellon \& Clayton (1983) have reported delayed puberty onset in ewe lambs superior cervical ganglionectomized at 6-8 weeks of age. After ganglionectomy melatonin levels were reported as $409 \pm 52 \mathrm{pmol} / 1$ during the day and $375 \pm 60 \mathrm{pmol} / 1$ at night. It is not possible to conclude that interruption of pineal function delayed puberty in the study by Yellon \& Clayton (1983) because the daytime levels of melatonin are comparable to levels we have obtained with Silastic melatonin implants (Kennaway \& Gilmore 1984). Nowak \& Rodway (1984) administered melatonin intravaginally to 8 - and 19-week-old lambs; at 19 weeks of age melatonin significantly advanced puberty but at 8 weeks there was no effect. The lack of information about dosage, melatonin levels achieved and duration of action make a comparison with the study of Kennaway \& Gilmore (1984) difficult, but the fact that melatonin was stimulatory in the lambs at 19 weeks of age supports the concept advanced for adult ewes, that constant melatonin administration simulates short day length (Kennaway, Gilmore \& Seamark, 1982). Photoperiodic influences are clearly involved in puberty onset in the ewe, there being a requirement for a period of long daylength followed by a period of short daylength (Yellon \& Foster, 1982a). Continuous melatonin administration can delay puberty (Kennaway \& Gilmore, 1984) and prevent the fall in prolactin concentrations associated with the first breeding season. Pinealectomy similarly delays puberty and appears to have a long-lasting effect (this study). 
How can this information be integrated to provide a working hypothesis for future studies? We have previously proposed that there is a circadian rhythm in melatonin receptor density in the ewe which develops during a critical period of the lambs development most likely between 10 and 20 weeks of age (Kennaway \& Gilmore, 1984). During the transition from long daylength (before puberty) to short daylength, melatonin is secreted progressively earlier each afternoon (Yellon \& Foster, 1982b). The appearance of melatonin in plasma may then interact with the rhythm of melatonin receptor density, triggering an as yet unknown response. Possibilities are the development of hypothalamic insensitivity to the feedback actions of oestradiol upon gonadotrophin secretion (Foster, 1981a), the establishment of the non-steroidal-dependent LHRH pulse mechanisms (Goodman \& Karsch, 1981) or changes in pituitary sensitivity to LHRH as described for neonatal rats (Martin, Engel \& Klein, 1977). While it is possible to reconcile all of the results obtained in lambs thus far with this hypothesis, indirect evidence from hamster experiments suggests such a receptor rhythm is unlikely (Silver \& Bittman, 1984). However, in view of the fundamentally different manner in which hamsters and sheep interpret the normal melatonin rhythm and continuous administration of the hormone (Reiter, 1980; Kennaway et al., 1982) the receptor rhythm hypothesis does warrant testing.

We thank Dr R. F. Seamark for his help and encouragement during this study; Mr P. Geytenbeek, Mr P. Van Beusichem, Mr P. Attick and Mr P. Steele of the Waite Institute and Mortlock Experiment Station for the use of the facilities, monitoring of oestrus and general care of the animals; and Miss S. Hodson and Miss T. Lloyd, for the progesterone assays. This work was supported by a grant from the National Health and Medical Research Council of Australia.

\section{References}

Bittman, E.L., Dempsey, R.J. \& Karsch, F.J. (1983) Pineal melatonin secretion drives the reproductive response to daylength in the ewe. Endocrinology 113, 2276-2283.

Ducker, M.J., Thwaites, C.J. \& Bowman, J.G. (1970) Photoperiodism in the ewe. 2. The effects of various patterns of decreasing daylength on the onset of oestrus in Clun Forest ewes. Anim. Prod. 12, 115-123.

Foster, D.L. (1981a) Mechanism for delay of first ovulation in lambs born in the wrong season (fall). Biol. Reprod. 25, 85-92.

Foster, D.L (1981b) Effect of artificially decreasing daylength on the initiation of ovulation in the lamb: Evidence for a critical photosensitive period. Biol. Reprod. 24, Suppl. 1 Abstr. 87.

Foster, D.L. \& Ryan, K.D. (1981) Endocrine mechanisms governing transition into adulthood in female sheep. J. Reprod. Fert., Suppl. 30, 75-90.

Foster, D.L., Lemons, J.A., Jaffe, R.B. \& Niswender, G.D. (1975) Sequential patterns of circulating luteinizing hormone and follicle stimulating hormone in female sheep from early postnatal life through the first estrous cycles. Endocrinology 97, 985-993.

Goodman, R.L. \& Karsch, F.J. (1981) The hypothalamic pulse generator: a key determinant of reproductive cycles in sheep. In Biological Clocks in Seasonal Reproductive Cycles, pp. 223-236. Eds B. K. Follett \& D. E. Follett. Wrights, Bristol.

Hafez, E.S.E. (1952) Studies on the breeding season and reproduction in the ewe. J.acric. Sci., Camb. 42, 189265

Janson, P.O., Amato, F., Weiss, T.J., Ralph, M.M. \&
Seamark, R.F. (1978) On the isolated perfused sheep ovary as a model for the study of ovarian function. Fert. Steril. 30, 230-236.

Kennaway, D.J. \& Gilmore, T.A. (1984) Effects of melatonin implants in ewe lambs. J. Reprod. Fert. $\mathbf{7 0}$, 39-45.

Kennaway, D.J. \& Gilmore, T.A. (1985) Effects of melatonin implants in ram lambs. J. Reprod. Fert. 73, 85-91.

Kennaway, D.J., Obst, J.M., Dunstan, E.A. \& Friesen, H.G. (1981a) Ultradian and seasonal rhythms in plasma gonadotropins, prolactin, cortisol and testosterone in pinealectomized rams. Endocrinology 108 , 639-646.

Kennaway, D.J., Matthews, C.D. \& Seamark, R.F. (1981b) Pineal function in pregnancy: studies in sheep and man. In Pineal Function, pp. 123-136. Eds R. F. Seamark \& C. D. Matthews. Elsevier, Amsterdam.

Kennaway, D.J., Gilmore, T.A. \& Seamark, R.F. (1982) Effects of melatonin implants on the circadian rhythm of plasma melatonin and prolactin in sheep. Endocrinology 110, 2186-2188.

Kennaway, D.J., Sanford, L.M., Godfrey, B. \& Friesen, H.G. (1983) Patterns of progesterone, melatonin and prolactin secretion in ewes maintained in four different photoperiods. J. Endocr. 97, 229-242.

Legan, S.J. \& Karsch, F.J. (1977) The endocrine control of seasonal reproductive function in the ewe: a marked change in response to the negative feedback action of estradiol on luteinizing hormone secretion. Endocrinology 101, 818-824. 
Martin, J.E., Engel, J.M. \& Klein, D.C. (1977) Inhibition of the in vitro pituitary response to luteinizing hormone-releasing hormone by melatonin, serotonin, and 5-methoxytryptophol. Endocrinology 100, 675680.

Nowak, R. \& Rodway, R.G. (1984) Advancement of the breeding season of ewes and lambs by intravaginal application of melatonin. J. Steroid Biochem. 20, 1461.

Quirke, J.F. (1981) Regulation of puberty and reproduction in female lambs: a review. Livestock Prod. Sci.8, 37-58.

Reiter, R.J. (1980) The pineal and its hormones in the control of reproduction in mammals. Endocrine Reviews 1, 109-131.

Rollag, M.D. \& Niswender, G.D. (1976) Radioimmunoassay of serum concentrations of melatonin in sheep exposed to different lighting regimes. Endocrinology 98, 482-489.
Silver, R. \& Bittman, E.L. (1984) Reproductive mechanisms: interaction of circadian and interval timing. Ann. N.Y. Acad. Sci. 423, 488-514.

Yellon, S.M. \& Clayton, J.A. (1983) Evidence that the pineal times puberty in the lamb. Biol. Reprod. 28, Suppl. 1, 46, Abstr.

Yellon, S.M. \& Foster, D.L. (1982a) Long days are required to initiate and sustain ovulatory cycles under short days in the lamb. Biol. Reprod. 26, Suppl., Abstr. 178.

Yellon, S.M. \& Foster, D.L. (1982b) Photoperiodmediated melatonin patterns in the lamb before and after puberty and in delayed puberty. Endocrinology 110, Suppl., Abstr. 150.

Received 3 August 1984 